\title{
Ectoenzymatic activity and bacterial dynamics along a trophic gradient in the Caribbean Sea
}

\author{
Johannes Rath, Christian Schiller, Gerhard J. Herndl* \\ Dept of Marine Biology, Institute of Zoology, University of Vienna, Althanstr. 14, A-1090 Vienna, Austria
}

\begin{abstract}
Bacterial biomass, potential bacterial production and ectoenzymatic activity were measured at 4 stations along a trophic gradient at the Atlantic Barrier Reef off Belize (Central America). We investigated the changes in the trophic status of this system, which we hypothesized would also lead to changes in the bacterial community. The bacterial community of the oligotrophic station was characterized by low biomass (mean $7.2 \mu \mathrm{g} \mathrm{Cl}^{-1}$ ) and low potential production rates (mean $9.2 \mu \mathrm{g} \mathrm{Cl}^{-1} \mathrm{~d}^{-1}$ ) as determined by seawater cultures whereas at the most eutrophic station bacterial biomass (mean $18.6 \mu \mathrm{g} \mathrm{Cl}^{-1}$ ) as well as potential bacterial production (mean $15.5 \mu \mathrm{g} \mathrm{Cl}^{-1} \mathrm{~d}^{-1}$ ) was significantly higher. Oligotrophic bacteria exhibit high potential turnover rates $\left(1.5 \mathrm{~d}^{-1}\right)$. Ectoenzymatic activity measurements with fluorogenic-substrate analogs showed distinct differences in the expression of certain enzymes at different trophic conditions. $\alpha$ - and $\beta$-D-glucosidase activity declined from eutrophic to oligotrophic in both per volume and per cell while leucine-aminopeptidase activity per cell was inversely correlated with the trophic status of the environment. Differences in ectoenzymatic activity are indicated by differences in both $V_{\max }$ and $K_{\mathrm{m}} . K_{\mathrm{m}}$ values of leucine-aminopeptidase clearly reflect the trophic situation. Substrate affinity was found to be higher in oligotrophic waters by 2 orders of magnitude as compared to eutrophic environments. Potential activity $\left(v_{\max }\right)$ of the extracellular enzymes tested was found to be correlated to potential bacterial production and bacterial biomass.
\end{abstract}

KEY WORDS: Bacteria - Enzymatic activity $\cdot$ Trophic gradient

\section{INTRODUCTION}

Studies on the variations of microbial parameters such as standing stocks and production rates along trophic gradients are rare but offer interesting insights into obviously changing food web structures with different trophic stages (Herndl 1991, Sorokin \& Mamaeva 1991, Peduzzi \& Herndl 1992). Understanding the processes causing these deviations is important to predict the frequently detected inversions of the food web pyramid (Dortch \& Packard 1989, Fuhrman et al. 1989). Although heterotrophic bacterial biomass decreases from eutrophic to oligotrophic waters, its contribution to total (auto- and heterotrophic) microbial biomass increases and exceeds in the euphotic zone of oligotrophic systems even the biomass of phytoplankton (Dortch \& Packard 1989, Fuhrman et

- Addressee for reprint requests al. 1989, Cho \& Azam 1990, Herndl 1991). Under such conditions bacterial biomass accounts for nearly $50 \%$ of the total particulate organic carbon (Cho \& Azam 1990). Bacterial production also declines towards oligotrophic systems (Billen et al. 1990. Herndl 1991, Sorokin \& Mamaeva 1991); it is difficult, however, to compare data given in the literature because of different methodology and conversion factors used (Riemann et al. 1987, Cole et al. 1988, Torréton et al. 1989. Heinänen \& Kuparinen 1991). Peduzzi \& Herndl (1992) pointed out that bacteria from oligotrophic environments have the ability to grow fast and this growth is stimulated by both the activity of phyto- and zooplankton. Cho \& Azam (1988) showed that in oligotrophic waters bacteria exhibit high turnover times.

Bacteria play a central role in the cycling of organic matter in the sea (Ittekkot et al. 1981, 1982, Torréton et al. 1989, Cho \& Azam 1990). Particulate organic matter (POM) and dissolved organic matter (DOM) are dominated by high-molecular-weight compounds and only 
a very small fraction comprises a molecular size which can be taken up directly by bacteria (Fuhrman \& Ferguson 1986, Kirchman \& Hodson 1986, Fuhrman 1987). Due to the activity of extracellular enzymes, highmolecular-weight compounds can be cleaved and substances are produced - monomers and small oligomers - suitable to be taken up by the bacterial community (Hollibaugh \& Azam 1983, Halemejko \& Chrost 1986 , Hoppe 1991). Potential ectoenzymatic activity has been related to a variety of different microbial parameters. Close correlations were found between potential $\alpha$-glucosidase activity and algal photosynthetic activity (Chrost et al. 1989) and between potential aminopeptidase activity and heterotrophic activity as well as bacterial secondary production and pelagic primary production (Lancelot \& Billen 1984, Karner \& Herndl 1992).

On the regulatory level, some of these enzymes seem to be inducable (Halemejko \& Chrost 1986, Chrost \& Overbeck 1987, Fontigny et al. 1987) or de-repressible (Halemejko \& Chrost 1986, Chrost \& Overbeck 1987. Münster 1991, Ammerman 1991). A more detailed knowledge, however, on regulatory mechanisms of enzyme expression would be helpful for interpreting enzymatic activity measured with various substrate analogs. Assays aimed to determine enzyme kinetics in different ecosystems resulted in $K_{\mathrm{m}}$ varying over 2 orders of magnitude (Hoppe et al. 1983, Halemejko \& Chrost 1986, Chrost \& Overbeck 1987, Fontigny et al. 1987). This large variation might be caused by different enzyme concentrations, competitive inhibition, occurrence of isoenzymes with different substrate affinities or methological differences, e.g. in the choice of substrate analogs.

In this paper we aimed to address the question whether or not changes in microbial parameters along a trophic gradient covary with differences in enzyme expression and enzyme characteristics.

\section{METHODS}

Study location and sampling. Investigations were carried out at the Atlantic Barrier Reef off Belize (Central America; $16^{\circ} 48^{\prime} \mathrm{N}, 88^{\circ} 05^{\prime} \mathrm{W}$ ) along a $2.5 \mathrm{~km}$ long transect from the outer reef to a mangrove island in the lagoon (Fig. 1). Stn 1, located at the outer reef, represents oceanic, oligotrophic waters; water depth was approximately $100 \mathrm{~m}$. In contrast Stn 4 , located at the end of the Lair Channel of the mangrove island Twin Cays, is considered to be eutrophic, characterized by turbid, brown waters with low transparency and high phytoplankton biomass $\left(13.85 \mu \mathrm{g}\right.$ chl a $\mathrm{l}^{-1}$; Herndl 1991). Stns 2 \& 3 represent intermediate situations; Stn 2, located in the 5 to $10 \mathrm{~m}$ deep lagoon, is strongly

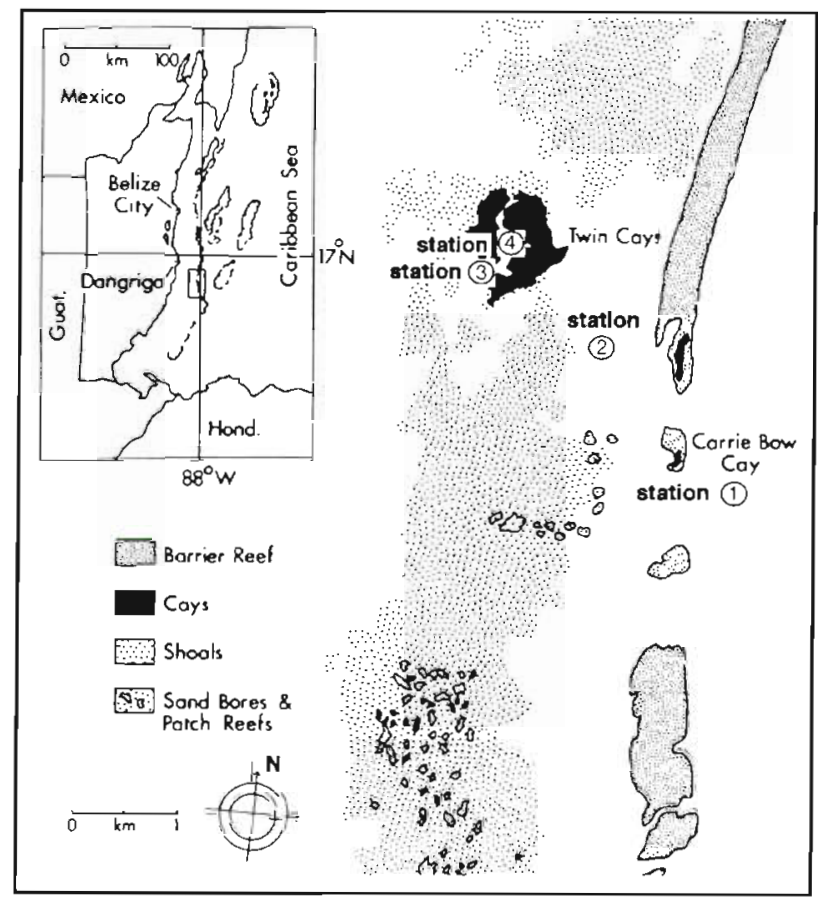

Fig. 1. Study location and sampling sites

influenced by incoming oligotrophic waters while Stn 3 is characterized by strong impact of eutrophic waters from the adjacent mangrove system. Water depth at Stns $3 \& 4$ was 3 to $10 \mathrm{~m}$. The samples were taken daily along a transect between 9:00 and 12:00 h in November 1991. Sampling was carried out with plastic syringes $(600 \mathrm{ml})$ which were presoaked with $1 \mathrm{~N} \mathrm{HCl}$ and prerinsed with water from the respective station. Water samples were taken daily from a depth of $0.5 \mathrm{~m}$, split and further processed within $2 \mathrm{~h}$ over a period of $10 \mathrm{~d}$.

Bacterial abundance and biomass. For enumerating bacteria, $5 \mathrm{ml}$ subsamples were fixed with $0.2 \mu \mathrm{m}$ filtered concentrated unbuffered formalin (final conc $2 \% \mathrm{w} / \mathrm{v})$, stained with $100 \mu \mathrm{l}$ of an acridine orange solution ( $1 \mathrm{mg} \mathrm{m}^{-1} ; 0.2 \mu \mathrm{m}$ filtered) for $3 \mathrm{~min}$ (Hobbie et al. 1977) and filtered onto black polycarbonate filters (Millipore, pore size $0.2 \mu \mathrm{m}$ ). Suction pressure during filtration did not exceed 200 mbar. Filters were embedded in paraffin oil and stored at $4^{\circ} \mathrm{C}$ in the dark until analysis. Enumeration was performed within 1 mo using a Leitz Laborlux S epifluorescence microscope. It has been shown recently that up to a 1 mo storage of samples provides realistic estimates of the actual cell density (Turley \& Hughes 1992). Thirty fields, or more than 300 bacteria, were counted per sample. For converting bacterial numbers into carbon equivalents a conversion factor of $20 \mathrm{fg} \mathrm{C}$ cell $^{-1}$ was used (Lee \& Fuhrman 1987). 
Bacterial production estimates. In order to estimate bacterial production, seawater cultures were used (Ammerman et al. 1984). Seawater samples $(20 \mathrm{ml}$, $0.6 \mu \mathrm{m}$ filtered) were incubated in $180 \mathrm{ml}$ of $0.2 \mu \mathrm{m}$ filtered seawater (Herndl 1991). These seawater cultures were held unagitated at ambient water temperature in the dark for $24 \mathrm{~h}$. Increases in cell density over $24 \mathrm{~h}$ were converted into carbon biomass production as described above.

Ectoenzymatic activity and leucine aminopeptidase kinetics. Ectoenzymatic activity was determined using fluorogenic substrate analogs (Hoppe 1983). For the determination of aminopeptidase activity L-leucine-7-amino-4-methyl coumarine (leu-MCA) was used. The determination of alkaline phosphatase, $N$-acetyl- $\beta$-D-glucosaminidase (chitobiase), lipase, $\alpha$ and $\beta$-D-glucosidase activity was performed with the corresponding 4-methyl umbelliferyl analogs; all chemicals were purchased from Sigma and stored at $-20^{\circ} \mathrm{C}$. Working solutions were prepared with MilliQ-water and added to $3 \mathrm{ml}$ of sample giving a final concentration of $2.5 \mu \mathrm{M}$. Incubation was done at in situ temperature for $60 \mathrm{~min}$. The fluorescent yield was measured with a Jasco 820 spectrofluorometer which was calibrated with standards (7-amino-4fluoromethyl coumarin and 4-methyl umbelliferone) of known concentrations. Enzyme kinetic assays were performed with leu-MCA in duplicates at 7 different substrate concentrations ranging from $100 \mathrm{nM}$ to $25 \mu \mathrm{M}$.

Statistical analysis. Statistical analysis were performed using the Systat software package (Wilkinson 1987).

\section{RESULTS}

\section{Bacterial biomass, potential bacterial roduction and potential bacterial turnover rate}

Bacterial biomass declined continuously from the most eutrophic Stn 4 (mean $18.6 \mu \mathrm{g} \mathrm{C}^{-1}$ ) to the most oligotrophic Stn 1 (mean $7.2 \mu \mathrm{g} \mathrm{Cl}^{-1}$; Fig. 2). Potential bacterial production as estimated by the dilution culture approach was highest at Stn 4 (mean $15.5 \mu \mathrm{g} \mathrm{C}$ $\mathrm{l}^{-1} \mathrm{~d}^{-1}$ ) and lowest at the oligotrophic Stn 1 (mean $9.2 \mu \mathrm{g} \mathrm{Cl}^{-1} \mathrm{~d}^{-1}$ ); the decline in potential bacterial production, however, was not as dramatic as the decline in bacterial biomass towards the more oligotrophic station (Table 1). These differences in the decline of biomass and potential production are reflected in the potential turnover rate of bacteria which increased by almost a factor of 2 from the most eutrophic Stn 4 (mean $0.8 \mathrm{~d}^{-1}$ ) to the most oligotrophic Stn 1 (mean $1.5 \mathrm{~d}^{-1}$; Table 1).

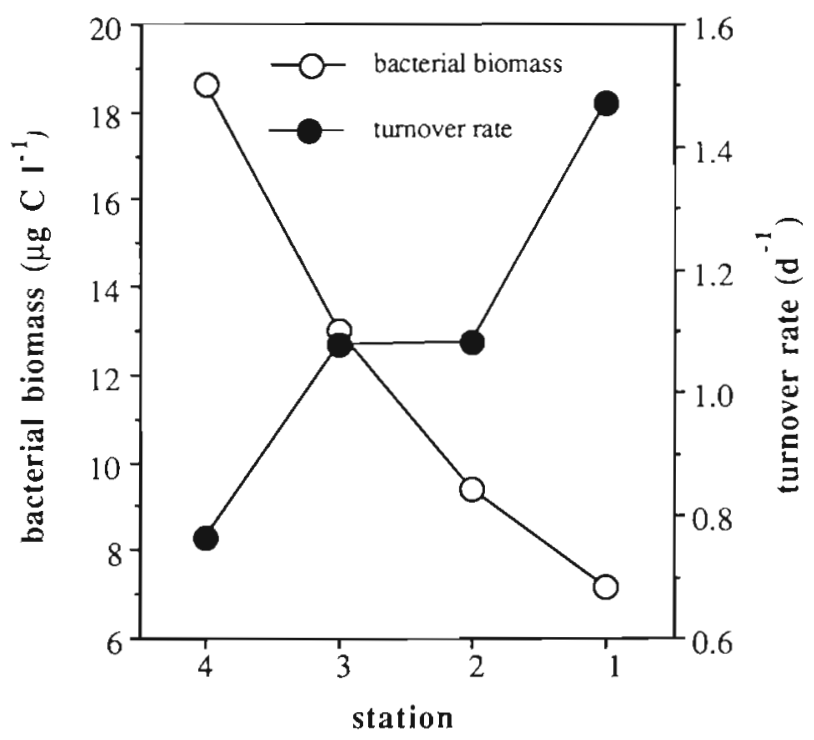

Fig. 2. Bacterial biomass and potential turnover rate along the trophic gradient. Stn 1 is the most oligotrophic station, Stn 4 is the most eutrophic mangrove station. For further details see Table 1

\section{Ectoenzymatic activity along the trophic gradient}

As shown in Table 1, leucine-aminopeptidase activity calculated on a per cell basis was found to depend significantly on the trophic condition of the environment (Kruskal Wallis, $\mathrm{p}<0.007$ ); leucine-aminopeptidase activity per cell at the most eutrophic Stn 4 (mean 316.0 amol cell ${ }^{-1} \mathrm{~h}^{-1}$ ) was about half the value of the oligotrophic Stn 1 (mean 765.7 amol cell ${ }^{-1} \mathrm{~h}^{-1}$ ). Chitobiase activity decreased from the eutrophic Stn 4 (mean $6.1 \mathrm{nmol} \mathrm{l}^{-1} \mathrm{~h}^{-1}$ ) to Stn 1 (mean $2.1 \mathrm{nmol} \mathrm{l}^{-1} \mathrm{~h}^{-1}$ ); calculated on a per cell basis, the activity was highest at the mesotrophic Stns $2 \& 3$ (mean 8.1 and $9.3 \mathrm{amol}$ cell ${ }^{-1} \mathrm{~h}^{-1}$ respectively). The activity of the 2 glucosidic enzymes - $\alpha$-D-glucosidase and $\beta$-D-glucosidase showed a similar pattern and decreased continuously from the eutrophic $\operatorname{Stn} 4$ (mean 1.6 and $1.8 \mathrm{nmol} \mathrm{l}^{-1} \mathrm{~h}^{-1}$ respectively) towards $\operatorname{Stn} 1\left(0.3 \mathrm{nmol} \mathrm{l}^{-1} \mathrm{~h}^{-1}\right.$ for both glucosidases). In contrast to chitobiase and leucineaminopeptidae activity, $\alpha$ - and $\beta$-glucosidase activity calculated on a per cell basis decreased steadily from the eutrophic mangrove-influenced Stn 4 (mean 1.7 and 1.8 amol cell ${ }^{-1} \mathrm{~h}^{-1}$ respectively) to the open water Stn 1 (mean 0.4 and $0.6 \mathrm{amol} \mathrm{cell}^{-1} \mathrm{~h}^{-1}$ respectively; see also Table 1).

Lipase activity per cell increased from Stn 4 (mean $124.4 \mathrm{amol} \mathrm{cell}^{-1} \mathrm{~h}^{-1}$ ) to Stn 1 (mean $350.7 \mathrm{amol} \mathrm{cell}^{-1}$ $\mathrm{h}^{-1}$ ). Alkaline phosphatase activity decreased from the eutrophic mangrove Stn 4 (mean $56.1 \mathrm{nmol} \mathrm{l}^{-1} \mathrm{~h}^{-1}$ ) to Stn 1 (mean $30.7 \mathrm{nmol} \mathrm{l}^{-1} \mathrm{~h}^{-1}$ ). 
Table 1. Distribution of bacterial and enzymatic parameters (mean $\pm \mathrm{SD}$, no. of measurements in parentheses) along a trophic gradient in the Caribbean Sea off Belize. Bacterial density is expressed in cells $\mathrm{ml}^{-1} \times 10^{5}$, bacterial biomass in $\mu \mathrm{g} \mathrm{Cl} l^{-1}$, potential bacterial production in $\mu \mathrm{g} \mathrm{Cl}^{-1} \mathrm{~d}^{-1}$, potential bacterial turnover rate $\mathrm{d}^{-1}$, enzymatic activity in nmol substrate released $\mathrm{l}^{-1} \mathrm{~h}^{-1}$ or amol substrate released cell $\mathrm{l}^{-1} \mathrm{~h}^{-1}$ Differences among the stations were tested with KruskalWallis 1 -way analysis of variance: $p<0.05 ; \cdots p<0.01$; $\cdots p<0.001$

\begin{tabular}{|c|c|c|c|c|}
\hline Parameter & $\begin{array}{c}\operatorname{Stn} 4 \\
\text { (eutrophic) }\end{array}$ & Stn 3 & Stn 2 & $\begin{array}{c}\text { Stn } 1 \\
\text { (oligo- } \\
\text { trophic) }\end{array}$ \\
\hline $\begin{array}{l}\text { Bacterial } \\
\text { density }\end{array}$ & $\begin{aligned} & 9.3 \cdots \\
& \pm 1.8 \\
&(8)\end{aligned}$ & $\begin{array}{c}\quad 6.5 \cdots \\
+2.6 \\
(8)\end{array}$ & $\begin{array}{c}\cdot \quad 4.7 \cdots \\
+1.1 \\
(8)\end{array}$ & $\begin{array}{l}3.6 \cdots \\
+1.2 \\
(8)\end{array}$ \\
\hline $\begin{array}{l}\text { Bacterial } \\
\text { biomass }\end{array}$ & $\begin{array}{c}18.6 \cdots \\
\pm 3.5 \\
(8)\end{array}$ & $\begin{array}{c}13.0 \cdots \\
+5.2 \\
(8)\end{array}$ & $\begin{array}{c}\cdot \quad 9.4 \cdots \\
\pm \\
(8)\end{array}$ & $\begin{array}{l}7.2 \cdots \\
\pm 2.4 \\
(8)\end{array}$ \\
\hline $\begin{array}{l}\text { Bacterial } \\
\text { production }\end{array}$ & $\begin{array}{c}15.5^{\circ} \\
\pm 4.3 \\
(8)\end{array}$ & $\begin{array}{c}11.6^{\circ} \\
+4.0^{\circ} \\
(7)\end{array}$ & $\begin{aligned} & 9.8^{\circ} \\
& \pm 2.5 \\
&(7)\end{aligned}$ & $\begin{aligned} & 9.2^{\circ} \\
&+ 4.9 \\
&(7)\end{aligned}$ \\
\hline $\begin{array}{l}\text { Turnover } \\
\text { rate }\end{array}$ & $\begin{array}{l}0.8^{\circ} \\
\pm 0.3 \\
(7)\end{array}$ & $\begin{array}{c}1.1^{\circ} \\
\pm 0.3 \\
(7)\end{array}$ & $\begin{array}{l}1.1^{\circ} \\
\pm 0.3 \\
(7)\end{array}$ & $\begin{array}{l}1.5^{\circ} \\
\pm 0.6 \\
(7)\end{array}$ \\
\hline $\begin{array}{l}\text { Alkaline } \\
\text { phosphatase } 1^{-1}\end{array}$ & $\begin{aligned} & 56.1^{\circ} \\
\pm & 37.6 \\
& (9)\end{aligned}$ & $\begin{array}{c}59.5^{\circ} \\
+26.7 \\
\quad(8)\end{array}$ & $\begin{aligned} & 52.6^{\circ} \\
\pm & 36.8 \\
& (7)\end{aligned}$ & $\begin{array}{l}30.7^{\circ} \\
\pm 15.0 \\
\quad(8)\end{array}$ \\
\hline $\begin{array}{l}\alpha \text {-glucosi- } \\
\text { dase } 1^{-1}\end{array}$ & 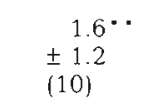 & $\begin{array}{l}\quad 0.7^{\cdots} \\
\pm 0.3 \\
(10)\end{array}$ & $\begin{aligned} & 0.5 \cdots \\
& \pm 0.6 \\
&(10)\end{aligned}$ & 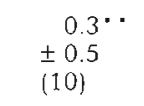 \\
\hline $\begin{array}{l}\beta \text {-glucosi- } \\
\text { dase } 1^{-1}\end{array}$ & $\begin{aligned} & 1.8^{\cdots} \\
& \pm 1.3 \\
&(10)\end{aligned}$ & 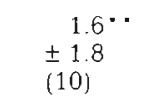 & $\begin{array}{l}\quad 0.6^{\cdots} \\
\pm 0.5 \\
(10)\end{array}$ & $\begin{array}{l}\quad 0.3^{\cdots} \\
\pm 0.4 \\
(10)\end{array}$ \\
\hline Chitobiase $1^{-1}$ & $\begin{array}{l}\quad 6.1 \cdots \\
\pm 3.0 \\
(10)\end{array}$ & $\begin{aligned} & 5.9 \cdots \\
& \pm 2.6 \\
&(9)\end{aligned}$ & $\begin{array}{l}\quad 4.6^{\circ} \\
\pm 2.6 \\
(10)\end{array}$ & $\begin{array}{c}2.1^{\cdots} \\
+1.6 \\
(9)\end{array}$ \\
\hline $\begin{array}{l}\text { Leucine-amino- } \\
\text { peptidase } l^{-1}\end{array}$ & $\begin{array}{r}280.5 \\
\pm 68.3 \\
(10)\end{array}$ & $\begin{array}{r}297.1 \\
+74.4 \\
(10)\end{array}$ & $\begin{array}{c}305.8 \\
\pm 79.4 \\
(10)\end{array}$ & $\begin{aligned} 246.5 \\
+131.3 \\
(10)\end{aligned}$ \\
\hline Lipase $1^{-1}$ & $\begin{array}{r}84.9 \\
+31.9 \\
(10)\end{array}$ & $\begin{array}{c}115.8 \\
\pm 47.6 \\
(10)\end{array}$ & $\begin{array}{c}95.3 \\
+36.3 \\
(10)\end{array}$ & $\begin{array}{r}99.4 \\
+17.7 \\
(10)\end{array}$ \\
\hline $\begin{array}{l}\alpha \text {-glucosidase } \\
\text { cell }{ }^{-1}\end{array}$ & $\begin{aligned} & 1.7^{\cdots} \\
&+ 1.1 \\
&(8)\end{aligned}$ & $\begin{array}{c}1.1 \cdots \\
\pm 0.4 \\
(8)\end{array}$ & $\begin{array}{c}0.9^{\cdots} \\
+0.9 \\
(8)\end{array}$ & $\begin{array}{c}0.4 \cdots \\
\pm 0.8 \\
(8)\end{array}$ \\
\hline $\begin{array}{l}\beta \text {-glucosidase } \\
\text { cell }^{-1}\end{array}$ & $\begin{aligned} & 1.8^{\circ} \\
&+ 1.1 \\
&(8)\end{aligned}$ & $\begin{aligned} & 1.8^{\circ} \\
& \pm 1.2 \\
&(8)\end{aligned}$ & $\begin{aligned} & 1.1^{\circ} \\
& \pm 1.0 \\
&(7)\end{aligned}$ & $\begin{array}{l}0.6^{\circ} \\
\pm 0.6 \\
(7)\end{array}$ \\
\hline $\begin{array}{l}\text { Chitobiase } \\
\text { cell }^{-1}\end{array}$ & $\begin{aligned} & 6.2 \\
& \pm 2.8 \\
&(8)\end{aligned}$ & $\begin{array}{r}8.1^{\circ} \\
\pm 3.9 \\
(8)\end{array}$ & $\begin{array}{c}9.3^{\circ} \\
\pm 5.2 \\
(8)\end{array}$ & $\begin{aligned} & 7.0^{\circ} \\
& \pm 5.7 \\
&(8)\end{aligned}$ \\
\hline $\begin{array}{l}\text { Leucine-amino- } \\
\text { peptidase cell }\end{array}$ & $\begin{array}{c}316.0 \cdots \\
+78.9 \\
(8)\end{array}$ & $\begin{array}{c}509.8 \cdots \\
\pm 209.2 \\
(8)\end{array}$ & $\begin{array}{c}654.7 \cdots \\
+194.4 \\
(8)\end{array}$ & $\begin{array}{c}765.7 \cdots \\
\pm 300.8 \\
(8)\end{array}$ \\
\hline Lipase cell ${ }^{-1}$ & $\begin{array}{c}124.5 \cdots \\
+73.4 \\
(8)\end{array}$ & $\begin{array}{c}196.3 \cdots \\
\pm 59.6 \\
(7)\end{array}$ & $\begin{array}{c}\quad 232.3 \cdots \\
+111.9 \\
(7)\end{array}$ & $\begin{aligned} & 350.7 \cdots \\
+ & 158.3 \\
& (7)\end{aligned}$ \\
\hline
\end{tabular}

\section{Enzyme kinetic assay}

Stns $1 \& 4$ showed clear differences in the kinetics of L-leucine-aminopeptidase (Fig. 3). $K_{\mathrm{m}}$ at Stn 1 $(0.59 \mu \mathrm{mol})$ was much lower than at the eutrophic $\operatorname{Stn} 4$ ( $47.6 \mu \mathrm{mol}$ ) on 5 November, although $v_{\max }$ values were very similar $\left(608\right.$ and $493 \mathrm{nmol} \mathrm{l}^{-1} \mathrm{~h}^{-1}$ at Stns 1 \& 4 respectively). On 7 November, the kinetic assay revealed a similar pattern (data not shown).

\section{Interdependence of bacterial parameters}

Bacterial biomass and potential bacterial production were found to be positively correlated (Table 2). A much closer correlation, however, was achieved between bacterial biomass and potential turnover rate (Table 2). This correlation was inverse, indicating that high potential turnover rates are associated with low bacterial biomass. No significant correlations were obtained between potential bacterial production and potential turnover rates. Enzyme activities calculated on a volume basis frequently revealed either no (leucine aminopeptidase, lipase) or positive correlations with bacterial biomass (Table 2). For example $\beta$-glucosidase and chitobiase showed strong positive correlation with bacterial biomass $(p<0.002$ and $p<$ 0.0005 respectively; see also Table 2 ). When correlating bacterial biomass with enzyme activity on a per cell basis, we detected negative correlations, indicating

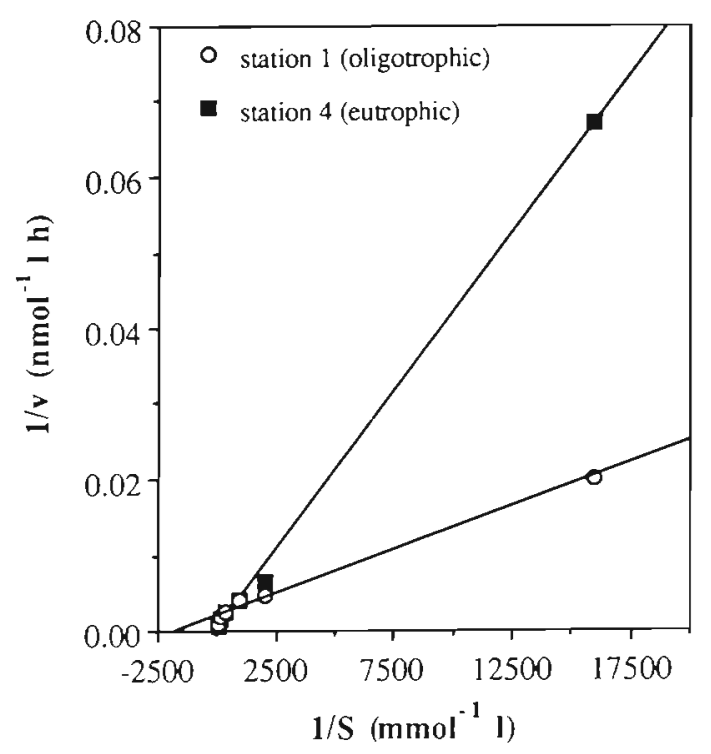

Fig. 3. Lineweaver-Burke plot of L-leucine-aminopeptidase (substrate, S) at Stn 1 (oligotrophic; $\mathrm{r}^{2}=0.999, \mathrm{n}=6$ ) and $\operatorname{Stn} 4$ (eutrophic; $r^{2}=0.992, n=6$ ),$v=v_{\max }$. Symbols represent mean of 2 replicates 
Table 2. Parameters of linear correlation equations $(y=a+b x)$ of different bacterial and enzymatic parameters. ns: not significant

\begin{tabular}{|c|c|c|c|c|c|c|}
\hline Independent variable & Dependent variable & a & $b$ & $\mathrm{n}$ & $r$ & $\mathrm{p}<$ \\
\hline Biomass & Production & 8.5 & +0.3 & 33 & 0.41 & 0.01 \\
\hline Biomass & P/B ratio & 1.7 & -4.7 & 29 & 0.56 & 0.002 \\
\hline Biomass & $\beta$-glucosidase $1^{-1}$ & 0.08 & +0.1 & 32 & 0.51 & 0.002 \\
\hline Biomass & Chitobiase $1^{-1}$ & 1.3 & +0.3 & 38 & 0.53 & 0.0005 \\
\hline Biomass & Leu-aminopep. $\mathrm{I}^{-1}$ & 291.4 & +0.9 & 33 & 0.003 & ns \\
\hline Biomass & $\alpha$-glucosidase cell ${ }^{-1}$ & 0.1 & +7.7 & 32 & 0.001 & ns \\
\hline Biomass & $\beta$-glucosidase cell-1 & 0.3 & -3.1 & 33 & 0.006 & ns \\
\hline Biomass & Leu-aminopep. cell ${ }^{-1}$ & 975.3 & -33.8 & 30 & 0.69 & 0.0005 \\
\hline Biomass & Lipase cell-1 & 471.5 & -20.5 & 31 & 0.69 & 0.0005 \\
\hline Biomass & Chitobiase cell-1 & 14.2 & -43.9 & 34 & 0.43 & 0.005 \\
\hline Production & Turnover rate & 0.9 & +2.3 & 30 & 0.19 & ns \\
\hline Production & $\alpha$-glucosidase $\mathrm{l}^{-1}$ & 0.4 & +3.1 & 34 & 0.14 & ns \\
\hline Production & $\beta$-glucosidase $]^{-1}$ & 1.4 & +1.3 & 30 & 0.02 & ns \\
\hline Production & Leu-aminopep. $1^{-1}$ & 429.8 & -11.2 & 32 & 0.71 & 0.0005 \\
\hline Production & Leu-aminopep. cell ${ }^{-1}$ & 1102.0 & -45.6 & 28 & 0.73 & 0.0005 \\
\hline Turnover rate & Lipase cell ${ }^{-1}$ & 44.6 & +156.8 & 26 & 0.59 & 0.001 \\
\hline Turnover rate & Chitobiase cell $^{-1}$ & 3.0 & +5.5 & 29 & 0.49 & 0.01 \\
\hline Alk. phosphatase $l^{-1}$ & Chitobiase cell-1 & 3.5 & +7.1 & 30 & 0.79 & 0.0005 \\
\hline$\alpha$-glucosidase $1^{-1}$ & $\beta$-glucosidase $]^{-1}$ & 0.4 & +0.3 & 40 & 0.39 & 0.01 \\
\hline Chitobiase $1^{-1}$ & $\alpha$-glucosidase $1^{-1}$ & 9.9 & +0.1 & 40 & 0.52 & 0.0005 \\
\hline Chitobiase $1^{-1}$ & $\beta$-glucosidase $1^{-1}$ & 0.4 & +0.2 & 40 & 0.40 & 0.01 \\
\hline
\end{tabular}

lower mean per cell expression of the enzyme with increasing biomass for leucine-aminopeptidase activity, chitobiase activity and lipase activity (for details see Table 2). For $\alpha$-glucosidase and $\beta$-glucosidase, however, no such correlation was found.

Inverse correlations between potential bacterial production and enzyme activity were detectable for leucine-aminopeptidase activity for both, on a volume basis as well as per cell (Table 2). This inverse relation, found in both cases, indicates lower expression of the enzyme with increasing production. Potential turnover rates were positively correlated with lipase and chitobiase activity per cell. A highly significant correlation between lipase and chitobiase activity per cell was detectable (Table 2). Alkaline phosphatase expressed on a volume basis correlated closely with chitobiase activity expressed per cell (Table 2).

\section{DISCUSSION}

Although bacteria are the dominant biomass component in oligotrophic systems (Dortch \& Packard 1989, Fuhrman et al. 1989, Cho \& Azam 1990, Herndl 1991) the absolute bacterial biomass found in oligotrophic situations is frequently lower compared to those found under eutrophic situations (Billen et al. 1990, Sorokin \& Mamaeva 1991). As shown in Fig. 1, bacterial biomass decreased continuously towards the oligotrophic Stns
$1 \& 2$. Potential bacterial production was also lower in oligotrophic stations; however, the decline was not as dramatic, resulting in an continuous increase in potential turnover rates towards oligotrophic systems (Fig. 2, Table 1). The potential of oligotrophic bacteria for high growth rates in low-nutrient systems has been shown recently (Yoshinaga et al. 1991). High turnover rates of bacterioplankton in oligotrophic situtations were also observed by Sorokin \& Mamaeva (1991). The acceleration of this turnover seems to be caused by a change in the primary control mechanism of the bacterioplankton. Grazing by zooplankton might have a greater impact in controlling bacterial populations in oligotrophic systems (Sorokin \& Mamaeva 1991). Billen et al. (1990) concluded, based on theoretical assumptions of bacterioplankton dynamics, that the lack of interdependence found between potential bacterial turnover rates and the trophic situation could be explained by a general bottom-up control mechanism for bacterioplankton. Our results seem to support a more complex pattern. Similar to Sorokin \& Mamaeva (1991) we propose that the increased influence of top-down control mechanisms towards oligotrophic situations effects the bacterial community by avoiding a 'climax stage' similar to the stationary phase in bacterial cultures. Top-down control of bacterioplankton seems to be a prerequisite for rapid cycling of nutrients in oligotrophic systems proposed as the 'spinning wheel concept' by Goldman (1984). Recently, Peduzzi \& Herndl 
(1992) showed the strong stimulatory effect of zooplankton and phytoplankton on bacterial growth in oligotrophic waters suggesting that nutrient turnover within the microbial loop is further accelerated by the activity of these organisms.

Activity of extracellular glycosidic enzymes such as $\alpha$-D-glucosidase, $\beta$-D-glucosidase and $N$-acetyl- $\beta$-Dglucosaminidase (chitobiase) decreased from eutrophic to oligotrophic stations. The high input of allochthonous organic matter especially the input of glycosidic-compounds from the adjacent mangrove forests and the release of large amounts of these substances from the high phytoplankton biomass at these stations may influence the levels of enzyme expression. A similar pattern was found also for alkaline phosphatase, an enzyme mainly produced by phytoplankton (Chrost \& Overbeck 1987). The increase in alkaline phosphatase activity towards eutrophic stations was very small compared to the increase in phytoplankton biomass which increased by 2 orders of magnitude from Stn 1 to Stn 4 (Herndl 1991), resulting in much higher alkaline phosphatase activity per phytoplankton cell under oligotrophic conditions.

Bacteria are the dominant producer of certain ectoenzymes and they are predominately bound to bacterial cell surfaces (Hoppe 1983, Somville 1984, Chrost 1991). Ectoenzymatic activity per bacterial cell has also been calculated although this calculation assumes that all cells of the bacterial community express the same amount of a particular enzyme which is most likely not true. $\alpha$ - and $\beta$-glucosidase activity per cell was found to be significantly higher at the eutrophic stations (Table 1). High concentrations of oligo- and polymeric glycosidic compounds may result in the induction of these enzyme systems (Münster 1991). Positive correlation of $\alpha$-glucosidase activity with phytoplankton biomass and dissolved monomeric carbohydrates (DMCHO) was shown by Karner et al. (1992). Per cell activity of leucine-aminopeptidase, an ectoenzyme involved in the degradation of proteins, was significiantly higher at the oligotrophic stations compared to the eutrophic stations. Münster (1991) showed that leucine-aminopeptidase activity is inversely correlated with leucine concentration, indicating high expression of this enzyme at low free amino acid concentrations typical for oligotrophic situations. A similar pattern was found for lipase activity which might be caused by the presence of coral mucus at Stns $1 \& 2$ (C. Schiller pers. comm.).

A close inverse relation was found between potential bacterial production and potential leucine-aminopeptidase activity (Table 2, Fig. 4). As noted above, Münster (1991) showed that high leucine-aminopeptidase activity is correlated with low dissolved free amino acid concentrations. Limitation of bacterial growth in

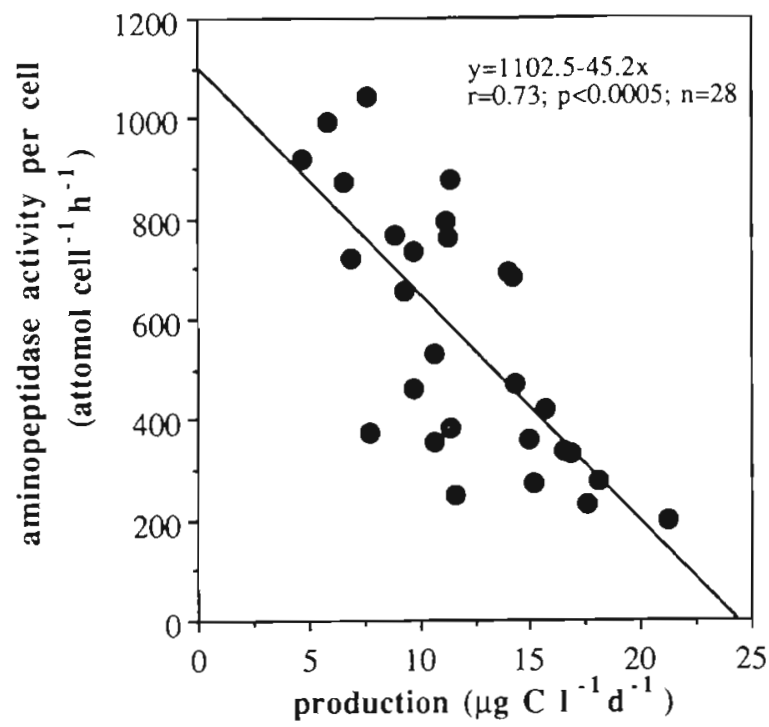

Fig. 4. Relation between potential bacterial production and L-leucine-aminopeptidase-activity. For further details see Table 2

the oligotrophic stations may therefore be caused by the availability of free amino acids. In this context it is remarkable that enzyme kinetics revealed distinctly different $K_{\mathrm{m}}$ values in different trophic environments. Considering $v_{\max }$, no such differences were detectable between the most offshore Stn 1 and the mangrove Stn 4 while $K_{\mathrm{m}}$ values differed over 2 orders of magnitude with a much higher substrate affinity of the enzyme at the oligotrophic $\operatorname{Stn} 1\left(K_{\mathrm{m}}=0.6 \mu \mathrm{mol}\right)$ compared to the mangrove Stn $4\left(K_{\mathrm{m}}=46.7 \mu \mathrm{mol}\right.$; Fig. 3$)$. Expression of isoenzymes with similar substrate specificity but different substrate affinity could potentially explain the large variations in $K_{\mathrm{m}}$ in the different trophic situations (Hodson et al. 1981, Cotner \& Wetzel 1991). The expression of extracellular enzymes with a high substrate affinity seems to be a strategy to support bacterial growth under low nutrient conditions. Competitive inhibition, however, is also known to alter $K_{\mathrm{m}}$ values (Hoppe 1983, Somville 1984). Higher protein concentration in the eutrophic Stn 4 may lead to higher $K_{\mathrm{m}}$ values (Fontigny et al. 1987).

In changing environments, where substrate concentrations may vary over a wide range, regulatory mechanisms of enzyme expression may exhibit a much greater influence on enzymatic activity than bacterial biomass. For example, in Escherichia coli induction of an enzyme results in an up to a 1000 -fold increase in enzyme expression (Gottschalk 1986). Therefore, correlations between bacterial biomass, bacterial production and enzymatic activities as shown in Table 2 may only be a secondary phenomenon caused by the availability of organic nutrients which influences both para- 
meters - bacterial production as well as expression of enzymes. Variations in the pool of inducer and repressor substances caused by uptake and release of these substances or mixing of the water body should result in corresponding fluctuations of enzymatic activity (Table 1).

Acknowledgements. This is contribution \#394, Caribbean Coral Reef Ecosystems (CCRE) Program, Smithsonian Institution. We thank Klaus Rützler and Mike Carpenter for their invaluable help. This study was partly supported by Exxon Corporation and by a grant of the Austrian Science Foundation (grant \#7748-BIO) to G.J.H. The comments of Hans Hoppe and Jörg A. Ott on a former draft of the manuscript is gratefully acknowledged. The work is in partial fulfillment of the requirements towards a Ph.D. degree at the University of Vienna by J.R.

\section{LITERATURE CITED}

A.nmerman, J. W. (1991). Role of ecto-phosphohydrolases in phosphorus regeneration in estuarine and coastal ecosystems. In: Chrost, R. J. (ed.) Microbial enzymes in aquatic environments. Springer Verlag, New York, p. 165-186

Ammerman, J. W., Fuhrman, J. A., Hagström, A., Azam, F. (1984). Bacterioplankton growth in seawater. I. Growth kinetics and cellular characteristics in seawater cultures. Mar. Ecol. Prog. Ser. 18: 31-39

Billen, G., Servais, P., Becquevort, S. (1990). Dynamics of bacterioplankton in oligotrophic and eutrophic aquatic environments: bottom-up or top-down control? Hydrobiologia 207: $37-42$

Cho, B. C., Azam, F. (1988). Major role of bacteria in biogeochemical fluxes in the ocean's interior. Nature 332 : $441-443$

Cho, B. C., Azam, F. (1990). Biogeochemical significance of bacterial biomass in the ocean's euphotic zone. Mar. Ecol. Prog. Ser. 63: 253-259

Cotner, J. B., Wetzel, R. G. (1991). Bacterial phosphatases from different habitats in a small, hardwater lake. In: Chrost, R. J. (ed.) Microbial enzymes in aquatic environments. Springer Verlag, New York, p. 187-205

Chrost, R. J. (1991). Environmental control of the synthesis and activity of aquatic microbial ectoenzymes. In: Chrost, R. J. (ed.) Microbial enzymes in aquatic environments. Springer Verlag, New York, p. 29-59

Chrost, R. J., Münster, U., Rai, H., Albrecht, D., Witzel, P. K., Overbeck, J. (1989). Photosynthetic production and exoenzymatic degradation of organic matter in the euphotic zone of a eutrophic lake. J. Plankton Res. 11: 223-242

Chrost, R. J., Overbeck, J. (1987). Kinetics of alkaline phosphatase activity and phosphorus availability for phytoplankton and bacterioplankton in Lake Plußsee (North German eutrophic lake). Microb. Ecol. 13: 229-248

Cole, J. J., Findlay, S., Pace, M. L. (1988). Bacterial production in fresh and saltwater ecosystems: a cross-system overview. Mar. Ecol. Prog. Ser. 43: 1-10

Dortch, Q., Packard, T T (1989). Differences in biomass structure between oligotrophic and eutrophic marine ecosystems. Deep Sea Res. 36: 223-240

Fontigny, A., Billen, G., Vives-Rego, J. (1987). Some kinetic characteristics of exoproteolytic activity in coastal seawater. Estuar. coast. Shelf Sci. 25: 127-133
Fuhrman, J. (1987). Close coupling between release and uptake of dissolved free amino acids in seawater studied by an isotope dilution approach. Mar. Ecol. Prog. Ser. 37. $45-52$

Fuhrman, J. A., Ferguson, R. L. (1986). Nanomolar concentrations and rapid turnover of dissolved free amino acids in seawater: agreement between chemical and microbiological measurements. Mar. Ecol. Prog. Ser. 33: 237-242

Fuhrman, J. A., Sleeter, T. D., Carlson, C. A., Proctor, L. M. (1989). Dominance of bacterial biomass in the Sargasso Sea and its ecological implications. Mar. Ecol. Prog. Ser 57: $207-217$

Goldman, J. C. (1984). Oceanic nutrient cycles. In: Fasham, M. J. R. (ed.) Flows of energy and materials in marine ecosystems. Plenum Press, New York, p. 137-170

Gottschalk, G. (1986). Bacterial metabolism. Springer-Verlag, New York

Halemejko, G. Z., Chrost, R. J. (1986). Enzymatic hydrolysis of proteinaceous particulate and dissolved material in an eutrophic lake. Arch. Hydrobiol. 107: 1-21

Heinänen, A., Kuparinen, J. (1991). Horizontal variation of bacterioplankton in the Baltic Sea. Appl. environ. Microbiol. 57: 3150-3155

Herndl, G. J. (1991). Microbial biomass dynamics along a trophic gradient at the Atlantic Barrier Reef off Belize (Central America). P.S.Z.N. I: Mar. Ecol. 12: 41-51

Hobbie, J. E., Daley, R. J., Jasper, S. (1977). Use of Nuclepore filters for counting bacteria by epifluorescence microscopy. Appl. environ. Microbiol. 33: 1225-1228

Hodson, R., Azam, F, Carlucci, A., Fuhrman, J., Karl, D., Holm-Hansen, O. (1981). Microbial uptake of dissolved organic matter in McMurdo Sound, Antarctica. Mar. Biol. 61: $89-94$

Hollibaugh, J. T., Azam, F. (1983). Microbial degradation of dissolved proteins in seawater. Limnol. Oceanogr. 28: 1104-1116

Hoppe, H.-G. (1983). Significance of exoenzymatic activities in the ecology of brackish water: measurements by means of methylumbelliferyl-substrates. Mar. Ecol. Prog. Ser. 11: 299-308

Hoppe, H.-G. (1991). Microbial extracellular enzyme activity: a new key parameter in aquatic ecology. In: Chrost, R. J. (ed.) Microbial enzymes in aquatic environments. Springer Verlag, New York, p. 60-83

Hoppe, H.-G., Gocke, K., Zamorano, D., Zimmermann, R. (1983). Degradation of macromolecular organic compounds in a tropical lagoon (Ciénaga Grande, Colombia) and its ecological significance. Int. Rev. ges. Hydrobiol. 68: $811-824$

Ittekkot, V., Brockmann, U., Michaelis, W., Degens, E. T. (1981). Dissolved free and combined carbohydrates during a phytoplankton bloom in the Northern North Sea. Mar. Ecol. Prog. Ser. 4: 299-305

Ittekkot, V., Degens, E. T., Brockmann, U. (1982). Monosaccharide composition of acid-hydrolyzable carbohydrates in particulate matter during a plankton bloom. Limnol. Oceanogr. $27 \cdot 770-776$

Karner, M., Fuks, D., Herndl, G. J. (1992). Bacterial activity along a trophic gradient. Microb. Ecol. 24: 243-257

Karner, M., Herndl, G. J. (1992). Extracellular enzymatic activity and secondary production in free-living and marine snow associated bacteria. Mar. Biol. 113: 341-347

Kirchman, D. L., Hodson, R. E. (1986). Metabolic regulation of amino acid uptake in marine waters. Limnol. Oceanogr. 31: $339-350$

Lancelot, C., Billen, G. (1984). Activity of heterotrophic bacteria and its coupling to primary production during the 
spring phytoplankton bloom in the southern bight of the North Sea. Limnol. Oceanogr. 29: 721-730

Lee, S., Fuhrman, J. A. (1987). Relationships between biovolume and biomass of naturally derived marine bacterioplankton. Appl. environ. Microbiol. 53: 1298-1303

Münster, U. (1991). Extracellular enzyme activity in eutrophic and polyhumic lakes. In: Chrost, R. J., Overbeck, J (eds.) Microbial enzymes in aquatic environments. Springer Verlag, New York, p. 96-122

Peduzzi, P., Herndl, G. J. (1992). Zooplankton activity fuelling the microbial loop: differential growth response of bacteria from oligotrophic and eutrophic waters. Limnol. Oceanogr. 37: 1087-1092

Riemann, B., Bjornsen, P. K., Newell, S., Fallon, R. (1987). Calculation of cell production of coastal marine bacteria based on measured incorporation of $\left.{ }^{3} \mathrm{H}\right]$ thymidine. Limnol. Oceanogr. 32: 471-476

Somville, M. (1984). Measurement and study of substrate

This article was submitted to the editor specificity of exoglucosidase activity in eutrophic water. Appl. environ. Microbiol. 48: 1181-1185

Sorokin, Y. I., Mamaeva, T. I. (1991). Role of planktonic bacteria in productivity and cycling of organic matter in the Eastern Pacific Ocean. Hydrobiologia 209: 39-50

Torréton, J.-P., Guiral, D., Arfi, R. (1989). Bacterioplankton biomass and production during destratification in a monomictic eutrophic bay of a tropical lagoon. Mar. Ecol. Prog. Ser. 57: 53-67

Turley, C. M., Hughes, D. J. (1992). Effects of storage on direct estimates of bacterial numbers of preserved seawater samples. Deep Sea Res. 39: 375-394

Wilkinson, L. (1987), SYSTAT the system for statistics. SYSTAT, Inc, Evanston, IL

Yoshinaga, 1., Fukami, K., Ishida, Y. (1991). Comparison of DNA and protein synthesis rates of bacterial assemblages between coral reef waters and pelagic waters in tropical ocean. Mar. Ecol. Prog. Ser. 76: 167-174

Manuscript first received: March 16, 1993

Revised version accepted: August 18, 1993 